\title{
KAJIAN TENTANG IZIN PADA INDUSTRI RUMAH TANGGA PANGAN*
}

\author{
Oleh \\ Ni Made Sellia** \\ Ida Bagus Putra Atmadja*** \\ Program Kekhususan Hukum Bisnis \\ Fakultas Hukum Universitas Udayana
}

\begin{abstract}
ABSTRAK
Karya ilmiah ini membahas permasalahan terkait konflik norma pada Undang-Undang Nomor 36 Tahun 2009 tentang Kesehatan dan Undang-Undang Nomor 18 Tahun 2012 tentang Pangan. Pasal 111 ayat (2) Undang-Undang Nomor 36 Tahun 2009 tentang Kesehatan menentukan bahwa makanan dan minuman hanya dapat diedarkan setelah mendapat izin edar sesuai dengan ketentuan peraturan perundang-undangan, sedangkan Pasal 91 ayat (2) Undang-Undang Nomor 18 Tahun 2012 tentang Pangan mengatur kewajiban memiliki izin edar dikecualikan terhadap pangan olahan tertentu yang diproduksi oleh industri rumah tangga. Tujuan dari penulisan karya ilmiah ini adalah untuk mengetahui izin pada industri rumah tangga pangan dan tanggung jawab pelaku usaha industri rumah tangga pangan terhadap pangan yang diedarkannya. Adapun metode penulisan yang digunakan adalah metode penelitian hukum normatif dengan pendekatan perundangundangan (The Statue Approach). Hasil dari penelitian ini adalah terkait pemberlakuan izin edar pada makanan dan minuman produksi industri rumah tangga pangan kemudian mengacu pada Undang-Undang Nomor 18 Tahun 2012 tentang Pangan berdasarkan asas lex specialis derogate legi generali. Meskipun izin edar dikecualikan pada industri rumah tangga pangan, namun industri rumah tangga pangan wajib untuk memiliki sertifikat produksi pangan industri rumah tangga (SPP-IRT).
\end{abstract}

Kata Kunci : industri rumah tangga, izin, pangan.

* Karya Ilmiah ini merupakan ringkasan di luar skripsi

** Ni Made Sellia, merupakan Mahasiswi dari Fakultas Hukum Universitas Udayana. Korespondensi : nmdsellia@gmail.com

*** Ida Bagus Putra Atmadja, merupakan Dosen dari Fakultas Hukum Universitas Udayana 
Adapun industri rumah tangga pangan juga bertanggung jawab terhadap pangan yang di edarkan. Hal ini berdasarkan UndangUndang Nomor 18 Tahun 2012 tentang Pangan, serta tanggung jawab hukum pelaku usaha dalam Undang-Undang Nomor 8 Tahun 1999 tentang Perlindungan Konsumen.

\section{ABSTRACT}

This writing investigated about conflict norm on The Act Numb. 36, 2009 concerning about Health and The Act Numb. 18, 2012 concerning about Food. Article Number 111 paragraph (2) about The Act Numb. 36, 2009 concerning about Health determined that food and drink only can for sale after have marketing permit according to regulation, while Article Number 91 paragraph (2) The Act Numb. 18, 2012 concerning about Food determined that obligation to have marketing permits is exclude for food that produced by home food industri. The aims of this writing are to know about permit on home food industry and responsibility of home food industry business performer towards their food. The method that is used in this writing is normative legal research and the statue approach. The result is marketing permits on home food industry refers to The Act Numb. 18, 2012 concerning about Food based on lex specialis derogate legi generali principle. Even marketing permits is not exclude on food home industry, but home food industri must have food produce certificate before sell its food and drinks products. Home food industry is also responsible with food and drinks that they produced, this is based on The Act Numb. 18, 2012 concerning about Food, and business performer commitment on The Act Number 8, 1999 concerning about Consumer Protection.

Keywords : home food industry, food, permit.

\section{PENDAHULUANN}

\subsection{Latar Belakang}

Dewasa ini, industri rumah tangga semakin berkembang dan menjadi salah satu penunjang perekonomian lokal. Hal ini terbukti dengan banyaknya pelaku bisnis dari kalangan pengusaha kecil dan menengah termasuk pelaku industri rumah tangga. Banyak keuntungan yang didapat dari industri rumah tangga, selain modal yang tidak terlalu besar, biaya 
sewa tempat usaha juga dapat ditekan. Sebagai contoh industri rumah tangga yang sering ditemui adalah industri rumah tangga pangan.

Menurut Penjelasan Pasal 91 ayat (2) Undang-Undang Nomor 18 Tahun 2012 tentang Pangan, industri rumah tangga pangan adalah industri pangan yang memiliki tempat usaha di tempat tinggal dengan peralatan pengolahan manual hingga semi otomatis. Lebih lanjut dijelaskan dalam Pasal 1 angka 1 Undang-Undang Nomor 18 Tahun 2012 tentang Pangan, yang dimaksud dengan pangan adalah segala sesuatu yang berasal dari sumber hayati produk pertanian, perkebunan, kehutanan, perikanan, peternakan, perairan, dan air, baik yang diolah maupun tidak diolah yang diperuntukkan sebagai makanan atau minuman bagi konsumsi manusia, termasuk bahan tambahan pangan, bahan baku pangan, dan bahan lainnya yang digunakan dalam proses penyiapan, pengolahan, dan/atau pembuatan makanan atau minuman.

Untuk mendirikan industri rumah tangga pangan, tentu terdapat syarat dan ketentuan yang harus dipenuhi. Hal ini guna mencapai penyelenggaraan sistem pangan yang memberi perlindungan baik bagi pihak yang memproduksi maupun yang mengkonsumsi pangan. ${ }^{1}$ Adapun salah satu syarat dan ketentuan tersebut adalah mengenai izin. Izin ini penting karena sebagai jaminan bahwa pangan olahan yang dijual oleh industri rumah tangga pangan sudah memenuhi standar produk pangan yang berlaku.

1 Mawar Dwi Yulianti dan Resmi Mustarichie, 2017, “Tata Cara Registrasi Untuk Pangan Olahan Industri Rumah Tangga (PIRT) Dan Makanan Dalam Negeri (MD) Dalam Rangka Peningkatan Produk Yang Aman Dan Bermutu Di Bandung Jawa Barat", URL: http://jurnal.unpad.ac.id/farmaka/article/download/14749/pdf diakses pada 16 Juni 2019 
Pasal 111 ayat (2) Undang-Undang Nomor 36 Tahun 2009 tentang Kesehatan (yang selanjutnya disebut sebagai Undang-Undang Kesehatan) menentukan bahwa makanan dan minuman hanya dapat diedarkan setelah mendapat izin edar sesuai dengan ketentuan peraturan perundang-undangan. Hal ini menunjukkan bahwa Undang-Undang Kesehatan dengan tegas menentukan jika setiap makanan dan minuman hanya dapat diedarkan setelah mendapat izin edar. Artinya sebelum mendapat izin edar, makanan dan minuman tidak dapat diedarkan pada masyarakat.

Pasal 91 ayat (2) Undang-Undang Nomor 18 Tahun 2012 tentang Pangan (yang selanjutnya disebut Undang-Undang Pangan) mengatur kewajiban memiliki izin edar dikecualikan terhadap pangan olahan tertentu yang diproduksi oleh industri rumah tangga. Dalam Undang-Undang Pangan menjelaskan bahwa pangan yang diproduksi oleh industri rumah tangga pangan tidak wajib untuk memiliki izin edar. Hal ini membuat persepsi bahwa izin edar dikecualikan terhadap setiap makanan dan minuman yang diproduksi oleh industri rumah tangga pangan, padahal Pasal 111 ayat (2) Undang-Undang Kesehatan mengatur bahwa makanan dan minuman hanya dapat diedarkan setelah mendapat izin edar.

Adanya konflik norma antara Pasal 111 ayat (2) UndangUndang Nomor 36 Tahun 2009 tentang Kesehatan dan Pasal 91 ayat (2) Undang-Undang Nomor 18 Tahun 2012 tentang Pangan menyebabkan suatu ketidakjelasan mengenai pengertian dari izin edar itu sendiri. Hal itu juga disebabkan karena baik dalam Undang-Undang Kesehatan maupun Undang-Undang Pangan tidak dijelaskan apa arti dari izin edar tersebut, sehingga diperlukan penjelasan lebih lanjut mengenai 
izin edar dan apakah izin edar tersebut diterapkan juga pada industri rumah tangga pangan. Selain itu, akan dibahas juga mengenai tanggung jawab pelaku usaha industri rumah tangga pangan terhadap pangan yang diedarkannya.

\subsection{Rumusan Masalah}

1. Bagaimana pengaturan hukum terkait izin pada industri rumah tangga pangan?

2. Bagaimana tanggung jawab pelaku usaha industri rumah tangga pangan terhadap pangan yang diedarkannya?

\subsection{Tujuan Penulisan}

Tujuan penulisan makalah ini adalah untuk mengetahui pengaturan hukum terkait izin pada industri rumah tangga pangan dan tanggung jawab pelaku usaha industri rumah tangga pangan terhadap pangan yang diproduksinya.

\section{ISI MAKALAH}

\subsection{Metode Penelitiana}

Metode yang digunakan dalam penelitian ini adalah metode penelitian hukum normatif. Menurut Soerjono Soekanto, penelitian hukum normatif adalah penelitian yang terdiri dari penelitian terhadap asas-asas hukum, sistematika hukum, dan taraf sinkronisasi hukum. ${ }^{2}$ Adapun pendekatan yang digunakan adalah pendekatan perundang-undangan (The Statue Approach), artinya adalah pendekatan yang dilakukan dengan meneliti berbagai macam peraturan perundangundangan yang berkaitan dengan tema hukum yang dibahas. ${ }^{3}$

\subsection{Hasil dan Pembahasan}

2 Bambang Sunggono, 2016, Metodologi Penelitian Hukum Ed. 1 Cet. 16, Rajawali Press, Jakarta, h. 41

3 Ibrahim Johnny, 2006, Teori Metodologi \& Penelitian Hukum Normatif, cet. II, Bayumedia Publishing, Malang, h. 302 


\subsubsection{Pengaturan Hukum Terkait Izin Pada Industri Rumah Tangga Pangan}

Pemenuhan pangan yang aman dan bermutu merupakan hak asasi manusia, tidak terkecuali pangan yang dihasilkan oleh industri rumah tangga. ${ }^{4}$ Berdasarkan hal ini, maka setiap pelaku usaha yang memproduksi pangan berkewajiban untuk memenuhi standarisasi pangan yang telah ditetapkan pemerintah demi pangan yang aman dan bermutu. Hal ini sesuai dengan Pasal 111 ayat (1) Undang-Undang Nomor 36 Tahun 2009 tentang Kesehatan yang menyatakan bahwa makanan dan minuman yang dipergunakan untuk masyarakat harus didasarkan pada standar dan/atau persyaratan kesehatan. Selain merupakan hak asasi manusia, pemenuhan standarisasi oleh pelaku usaha pangan juga merupakan bentuk perlindungan hukum terhadap konsumen.

Standarisasi merupakan proses penyusunan serta penerapan aturan-aturan dalam pendekatan secara teratur bagi kegiatan tertentu untuk kemanfaatan dan dengan kerjasama dari semua pihak yang berkepentingan, khususnya untuk meningkatkan penghematan menyeluruh secara optimum dengan memperhatikan kondisi fungsional dan persyaratan keamanan. ${ }^{5}$ Salah satu standarisasi yang harus dipenuhi oleh pelaku usaha pangan termasuk industri rumah tangga pangan adalah mengenai izin terkait pangan yang diproduksinya.

Izin menurut R. Kosim Adisoeputra diartikan sebagai perbuatan pemerintah yang memperkenankan suatu

${ }^{4}$ Anonim, 2019, "Penyuluhan Keamanan Pangan Dalam Rangka Sertifikasi Produksi Industri Rumah Tangga Pangan (IRTP)" URL: https://sumbabaratkab.go.id/?p=2460 diakses pada 15 Mei 2019

5 Aulia Muthiah, 2018, Hukum Perlindungan Konsumen, Pustaka Baru Press, Yogyakarta, h. 73 
perbuatan yang dilarang oleh peraturan yang bersifat umum. Pengertian izin ini apabila dihubungkan dengan izin produk pangan dapat ditarik unsur-unsurnya yaitu pemerintah melalui peraturan perundang-undangan melarang peredaran pangan olahan tanpa adanya suatu izin, dan peraturan yang mengatur tentang izin produk pangan bersifat umum (hukum publik). ${ }^{6}$

Industri rumah tangga pangan merupakan salah satu industri kecil menengah yang memproduksi pangan olahan dalam kemasan berlabel. 7 Pangan olahan yang dimaksud adalah makanan atau minuman hasil proses dengan cara atau metode tertentu dengan atau tanpa bahan tambahan. Pasal 91 ayat (1) Undang-Undang Pangan menentukan bahwa setiap pangan olahan yang dibuat didalam negeri atau yang diimpor untuk diperdagangkan dalam kemasan eceran wajib memiliki izin edar. Mengacu pada Peraturan Badan Pengawas Obat dan Makanan Nomor 27 Tahun 2017 tentang Pendaftaran Pangan Olahan, izin edar adalah persetujuan hasil penilaian pangan olahan yang diterbitkan oleh kepala badan dalam rangka peredaran pangan olahan. Adapun yang dimaksud kepala badan disini adalah Badan Pengawas Obat dan Makanan Republik Indonesia (BPOM RI).

Peraturan Badan Pengawas Obat dan Makanan Nomor 27 Tahun 2017 tentang Pendaftaran Pangan Olahan menjelaskan bahwa untuk mendapat izin edar dilakukan

${ }^{6}$ Edy Nurcahyo, 2018, "Pengaturan dan Pengawasan Produk Pangan Olahan Kemasan", Jurnal Magister Hukum Udayana Vol. 7, No. 3 : 402-407 URL: https://ojs.unud.ac.id/index.php/jmhu/article/view/42227/25869 diakses 16 Juni 2019

7 Wiwit Arif Wijaya dan Winiati P. Rahayu, 2014, "Pemenuhan Regulasi Perlabelan Produk Industri Rumah Tangga Pangan (IRTP) di Bogor", Jurnal Mutu Pangan Vol. 1(1): 65-73 URL: http://repository.ipb.ac.id/handle/123456789/69583 diakses 7 Juni 2019 
dengan cara melakukan pendaftaran pada Badan Pengawas Obat dan Makanan Republik Indonesia (BPOM RI). Adapun izin edar yang dikeluarkan oleh BPOM-RI menurut Pasal 75 Peraturan Badan Pengawas Obat dan Makanan Nomor 27 Tahun 2017 tentang Pendaftaran Pangan Olahan adalah BPOM RI MD untuk produksi pangan olahan dalam negeri, dan BPOM RI ML untuk pangan olahan produksi luar negeri.

Pasal 91 ayat (2) Undang-Undang Pangan menentukan jika kewajiban memiliki izin edar dikecualikan terhadap pangan olahan tertentu yang diproduksi oleh industri rumah tangga. Hal ini sejalan dengan Pasal 3 ayat (1) huruf a Peraturan Badan Pengawas Obat dan Makanan Nomor 27 Tahun 2017 tentang Pendaftaran Pangan Olahan, yang menyatakan bahwa izin edar dikecualikan terhadap pangan olahan yang diproduksi oleh industri rumah tangga pangan.

Meskipun izin edar dikecualikan terhadap pangan olahan yang diproduksi oleh industri rumah tangga pangan, namun menurut Pasal 43 Peraturan Pemerintah Nomor 28 Tahun 2004 tentang Keamanan, Mutu, dan Gizi Pangan menentukan bahwa pangan olahan yang diproduksi oleh industri rumah tangga wajib memiliki sertifikat produksi pangan industri rumah tangga (SPP-IRT) yang diterbitkan oleh Bupati/Walikota dan Kepala Badan POM menetapkan pedoman pemberian SPPIRT.

Berdasarkan hal tersebut, terkait pemberlakuan izin edar pada makanan dan minuman produksi industri rumah tangga pangan kemudian mengacu pada Undang-Undang Nomor 18 Tahun 2012 tentang Pangan berdasarkan asas lex specialis derogate legi generali. Asas lex specialis derogate legi generali berarti peraturan perundang-undangan yang bersifat khusus 
mengesampingkan peraturan perundang-undangan yang bersifat umum. Asas ini digunakan terkait adanya konflik horisontal ekstern, yaitu dapat terjadi antara satu norma dengan norma lain dari undang-undang yang berbeda. ${ }^{8}$

Dalam Lampiran Undang-Undang Nomor 23 Tahun 2014 tentang Pemerintah Daerah sebagaimana telah diubah dengan Undang-Undang Nomor 9 Tahun 2015 menyatakan bahwa pemerintah daerah kabupaten/kota melaksanakan penerbitan izin produksi makanan dan minuman pada industri rumah tangga, (2) pengawasan post market produk makanan dan minuman industri rumah tangga.

Sementara itu, Peraturan Pemerintah Nomor 38 Tahun 2007 tentang Pembagian Urusan Pemerintahan Antara Pemerintah, Pemerintah Daerah Provinsi, dan Pemerintah Daerah Kabupaten/Kota pada Bidang Kesehatan - sub bidang Obat dan Perbekalan Kesehatan, mengamanatkan bahwa pengawasan dan registrasi makanan dan minuman produksi rumah tangga merupakan urusan pemerintahan yang wajib diselenggarakan oleh pemerintah daerah kabupaten/kota atau dalam hal ini adalah Dinas Kesehatan Kabupaten/Kota.

Dalam hal pedoman pemberian sertifikat produksi pangan industri rumah tangga (SPP-IRT), ditetapkan oleh Kepala Badan POM yang diatur dalam Peraturan Kepala Badan Pengawas Obat dan Makanan Republik Indonesia Nomor HK.03.1.23.04.12.2205 Tahun 2012 tentang Pedoman Pemberian Sertifikat Produksi Pangan Industri Rumah Tangga. Menurut peraturan ini, Sertifikat Produksi Pangan Industri Rumah Tangga yang selanjutnya disingkat SPP-IRT adalah

8 I Made Pasek Diantha, 2017, Metodologi Penelitian Hukum Normatif dalam Justifikasi Teori Hukum, Prenada Media Group, Jakarta, h. 157 
jaminan tertulis yang diberikan oleh Bupati/Walikota terhadap pangan produksi industri rumah tangga pangan di wilayah kerjanya yang telah memenuhi persyaratan pemberian SPP-IRT dalam rangka peredaran pangan produksi industri rumah tangga pangan.

Berdasarkan Peraturan Kepala Badan Pengawas Obat dan Makanan Republik Indonesia Nomor HK.03.1.23.04.12.2205 Tahun 2012 tentang Pedoman Pemberian Sertifikat Produksi Pangan Industri Rumah Tangga, pemberian SPP-IRT ini ditandai dengan adanya nomor PIRT yang terdiri dari 15 digit dan berlaku selama 5 tahun dan dapat diperpanjang apabila masih memenuhi ketentuan. Adapun nomor PIRT wajib dicantumkan pada kemasan pangan produksi industri rumah tangga pangan.

Adapun tidak semua pangan olahan yang diproduksi oleh industri rumah tangga pangan dapat memperoleh sertifikat produksi pangan industri rumah tangga (SPP-IRT). Berdasarkan Peraturan Badan Pengawas Obat dan Makanan Nomor 22 Tahun 2018 tentang Pedoman Pemberian Produksi. Pangan Industri Rumah Tangga, adapun pangan yang dikecualikan untuk mendapat sertifikat produksi pangan industri rumah tangga (SPP-IRT) diantaranya:

a. Pangan yang diproses dengan sterilisasi komersial atau pasteurisasi

b. Pangan yang diproses dengan pembekuan (frozen food) yang penyimpanannya memerlukan lemari pembeku

c. Pangan olahan asal hewan yang disimpan dingin/beku

d. Pangan diet khusus dan pangan keperluan medis khusus, antara lain MP-ASI, booster ASI, formula bayi, formula lanjutan, pangan untuk penderita diabetes. 


\subsubsection{Tanggung Jawab Pelaku Usaha Industri Rumah Tangga Pangan Terhadap Pangan Yang Diedarkannya}

Tanggung jawab adalah suatu akibat dari kebebasan seseorang tentang perbuatannya atau tentang apa yang telah dilakukan. ${ }^{9}$ Dalam hal pelaku usaha industri rumah tangga pangan mengedarkan makanan/minuman hasil produksinya, terikat dengan peraturan perundangan-undangan sehingga dibebani tanggung jawab hukum. Hal ini sejalan dengan pendapat Apeldoorn yang dikutip dari Buku Ajar Sosiologi Hukum, menyatakan bahwa hukum dibebani oleh tanggung jawab hukum dipahami dan diamalkan masyarakat. Adapun tanggung jawab tersebut sesuai dengan kondisi masyarakat saat ini. ${ }^{10}$

Dalam bagian Penjelasan Undang-Undang Nomor 18 Tahun 2012 tentang Pangan, disebutkan bahwa pelaku usaha pangan bertanggung jawab terhadap pangan yang di edarkan, terutama apabila pangan yang diproduksi menyebabkan kerugian baik terhadap gangguan kesehatan maupun kematian orang yang mengkonsumsi pangan tersebut. Dalam hukum perlindungan konsumen, tanggung jawab ini disebut dengan tanggung jawab produk. Tanggung jawab produk atau product liability adalah suatu tanggung jawab secara hukum dari orang atau badan yang menghasilkan suatu produk atau dari orang atau badan yang bergerak dalam suatu proses untuk menghasilkan suatu produk, atau dari orang atau badan yang menjual atau mendistribusikan produk tersebut. ${ }^{11}$

\footnotetext{
9 Soekidjo Notoatmodjo, 2010, Etika dan Hukum Kesehatan, Rineka Cipta, Jakarta, h. 21

${ }^{10}$ I Gusti Ngurah Dharma Laksana et. al., 2017, Buku Ajar Sosiologi Hukum, Pustaka Ekspresi, Tabanan H. 9

11 Celina Tri Siwi Kristiyanti, 2011, Hukum Perlindungan Konsumen Ed. 1 Cet. 3, Sinar Grafika, Jakarta, h. 101
} 
Adapun sistem tanggung jawab dalam product liability berlaku prinsip strict liability atau prinsip tanggung jawab mutlak. ${ }^{12}$ Undang-Undang Nomor 8 Tahun 1999 tentang Perlindungan Konsumen telah menggunakan prinsip semistrict liability. ${ }^{13}$ Dalam Pasal 19 Undang-Undang Perlindungan Konsumen, disebutkan tanggung jawab pelaku usaha yang diantaranya adalah :

(1) Pelaku usaha bertanggung jawab memberi ganti rugi atas kerusakan, pencemaran, dan/atau kerugian konsumen akibat mengkonsumsi barang dan/atau jasa yang dihasilkan atau diperdagangkan.

(2) Ganti rugi sebagaimana dimaksud tersebut dapat berupa pengembalian uang atau penggantian barang dan/atau jasa yang sejenis atau setara nilainya, atau perawatan kesehatan dan/atau pemberian santunan yang sesuai dengan ketentuan peraturan perundang-undangan yang berlaku.

(3) Pemberian ganti rugi dilaksanakan dalam tenggang waktu 7 (tujuh) hari setelah tanggal transaksi

(4) Pemberian ganti rugi sebagaimana dimaksud ayat (1) dan ayat (2) tidak menghapuskan adanya kemungkinan tuntutan pidana berdasarkan pembuktian lebih lanjut mengenai adanya unsur kesengajaan.

(5) Ketentuan sebagaimana dimaksud pada ayat (1) dan ayat (2) tidak berlaku apabila pelaku usaha dapat membuktikan bahwa kesalahan tersebut merupakan kesalahan konsumen.

Dalam pertanggungjawaban mutlak atau strict liability, konsumen sebagai penggugat tidak diwajibkan lagi membuktikan kesalahan pelaku usaha sebagai tergugat. Sebab menurut prinsip ini, dasar pertanggungjawaban bukan lagi

12 Ibid, h. 105
13 Ibid, h. 106 
kesalahan melainkan pelaku usaha tergugat langsung bertanggung jawab sebagai resiko dari usahanya. Di lain pihak, pelaku usaha yang harus membuktikan bahwa dia tidak bersalah, yaitu bahwa dia telah melakukan proses produksi sesuai dengan ketentuan yang berlaku, dengan memegang teguh prinsip kehati-hatian dalam berproduksi. ${ }^{14}$

Berdasarkan hal tersebut, kegiatan usaha yang dilakukan oleh pelaku usaha wajib dilaksanakan sesuai dengan ketentuan peraturan yang berlaku, ketika terjadi pelanggaran terhadap peraturan yang telah ditetapkan, pelaku usaha wajib bertanggungjawab atas segala kerugian yang dialami konsumen akibat perbuatannya. ${ }^{15}$ Adapun tanggung jawab tersebut adalah berupa ganti kerugian sebagaimana diamatkan oleh Undang-Undang Perlindungan Konsumen.

\section{PENUTUP}

\subsection{Kesimpulan}

Izin edar dikecualikan untuk industri rumah tangga pangan, namun industri rumah tangga pangan diwajibkan untuk memiliki sertifikat produksi pangan industri rumah tangga (SPP-IRT) yang diterbitkan oleh Bupati/Walikota atau dalam hal ini adalah Dinas Kesehatan dan Kepala Badan POM menetapkan pedoman pemberian SPP-IRT tersebut. Pelaku usaha industri rumah tangga pangan juga bertanggung jawab terhadap setiap pangan yang di edarkannya. Hal ini sebagaimana ditentukan dalam bagian Penjelasan UndangUndang Nomor 18 Tahun 2012 tentang Pangan, selain itu

14 Aulia Muthiah, op.cit, h. 136

15 Gde Manik Yogiartha, 2016, "Tanggungjawab Pelaku Usaha Terkait Dengan Jual-Beli Telepon Seluler Tanpa Garansi", Jurnal Magister Hukum Udayana Vol. 5, No. 1 : 93-100 URL: https://ojs.unud.ac.id/index.php/imhu/article/view/20613/14457 diakses 16 Juni 2019 
pelaku usaha industri rumah tangga pangan juga memiliki tanggung jawab hukum berdasarkan Undang-Undang Nomor 8 Tahun 1999 tentang Perlindungan Konsumen.

\subsection{Saran}

1) Masyarakat diharapkan dapat lebih selektif untuk mengkonsumsi makanan atau minuman yang dijual di pasaran.

2) Pemerintah diharapkan dapat lebih mensosialisasikan mengenai izin yang harus dimiliki oleh industri rumah tangga pangan. Hal ini terkait dengan kemanan pangan yang diproduksi oleh industri rumah tangga pangan sebagai bentuk perlindungan hukum terhadap konsumen.

\section{DAFTAR PUSTAKA}

\section{Buku :}

Dharma Laksana, I Gusti Ngurah, et. al., 2017, Buku Ajar Sosiologi Hukum, Pustaka Ekspresi, Tabanan.

Johnny, Ibrahim, 2006, Teori Metodologi \& Penelitian Hukum Normatif, cet. II, Bayumedia Publishing, Malang.

Muthiah, Aulia, 2018, Hukum Perlindungan Konsumen, Pustaka Baru Press, Yogyakarta.

Notoatmodjo, Soekidjo, 2010, Etika dan Hukum Kesehatan, Rineka Cipta, Jakarta.

Pasek Diantha, I Made, 2017, Metodologi Penelitian Hukum Normatif dalam Justifikasi Teori Hukum, Prenada Media Group, Jakarta.

Sunggono, Bambang, 2016, Metodologi Penelitian Hukum Ed. 1 Cet. 16, Rajawali Press, Jakarta.

Tri Siwi Kristiyanti, Celina, 2011, Hukum Perlindungan Konsumen Ed. 1 Cet. 3, Sinar Grafika, Jakarta.

\section{Jurnal Ilmiah :}

Edy Nurcahyo, 2018, "Pengaturan dan Pengawasan Produk Pangan Olahan Kemasan", Jurnal Magister Hukum Udayana Vol

$$
7, \quad \text { No. }
$$$$
3
$$$$
\text { 402-407 }
$$

URL: 
https://ojs.unud.ac.id/index.php/jmhu/article/view/42227/ 25869 diakses 16 Juni 2019

Gde Manik Yogiartha, 2016, "Tanggungjawab Pelaku Usaha Terkait Dengan Jual-Beli Telepon Seluler Tanpa Garansi", Jurnal Magister Hukum Udayana Vol. 5, No. 1 : 93-100 URL: https://ojs.unud.ac.id/index.php/jmhu/article/view/20613/ 14457 diakses 16 Juni 2019

Wiwit Arif Wijaya dan Winiati P. Rahayu, 2014, "Pemenuhan Regulasi Perlabelan Produk Industri Rumah Tangga Pangan (IRTP) di Bogor", Jurnal Mutu Pangan Vol. 1(1): 65-73 URL: http://repository.ipb.ac.id/handle/123456789/69583 diakses 7 Juni 2019

Artikel :

Anonim, 2019, "Penyuluhan Keamanan Pangan Dalam Rangka Sertifikasi Produksi Industri Rumah Tangga Pangan (IRTP)" URL: https://sumbabaratkab.go.id/? $p=2460$ diakses pada 15 Mei 2019

Mawar Dwi Yulianti dan Resmi Mustarichie, 2017, "Tata Cara Registrasi Untuk Pangan Olahan Industri Rumah Tangga (PIRT) Dan Makanan Dalam Negeri (MD) Dalam Rangka Peningkatan Produk Yang Aman Dan Bermutu Di Bandung Jawa Barat", URL: http://jurnal.unpad.ac.id/farmaka/article/download/14749/ pdf diakses pada 16 Juni 2019

Peraturan Perundang-undangan :

Indonesia, Undang-Undang Nomor 8 Tahun 1999 tentang Perlindungan Konsumen, Lembaran Negara Republik Indonesia Tahun 1999 Nomor 42, Tambahan Lembaran Negara Republik Indonesia Nomor 3821.

Indonesia, Undang-Undang Nomor 36 Tahun 2009 tentang Kesehatan, Lembaran Negara Republik Indonesia Tahun 2009 Nomor 144, Tambahan Lembaran Negara Republik Indonesia Nomor 5063.

Indonesia, Undang-Undang Nomor 18 Tahun 2012 tentang Pangan, Lembaran Negara Republik Indonesia Tahun 2012 Nomor 227, Tambahan Lembaran Negara Republik Indonesia Nomor 5360.

Indonesia, Undang-Undang Nomor 9 Tahun 2015 tentang Perubahan Kedua Atas Undang-Undang Nomor 23 Tahun 2014 tentang Pemerintahan Daerah, Lembaran Negara Republik Indonesia Tahun 2015 Nomor 58, Tambahan Lembaran Negara Republik Indonesia Nomor 5679. 
Indonesia, Peraturan Pemerintah Nomor 28 Tahun 2004 tentang Keamanan, Mutu, dan Gizi Pangan, Lembaran Negara Republik Indonesia Tahun 2004 Nomor 107, Tambahan Lembaran Negara Republik Indonesia Nomor 3867.

Indonesia, Peraturan Pemerintah Nomor 38 Tahun 2007 tentang Pembagian Urusan Pemerintahan Antara Pemerintah, Pemerintah Daerah Provinsi, dan Pemerintah Daerah Kabupaten/Kota pada Bidang Kesehatan - sub bidang Obat dan Perbekalan Kesehatan, Lembaran Negara Republik Indonesia Nomor 82 Tahun 2007, Tambahan Lembaran Negara Republik Indonesia Nomor 4737.

Peraturan Kepala Badan Pengawas Obat dan Makanan Republik Indonesia Nomor HK.03.1.23.04.12.2205 Tahun 2012 tentang Pedoman Pemberian Sertifikat Produksi Pangan Industri Rumah Tangga.

Peraturan Badan Pengawas Obat dan Makanan Nomor 27 Tahun 2017 tentang Pendaftaran Pangan Olahan.

Peraturan Badan Pengawas Obat dan Makanan Nomor 22 Tahun 2018 tentang Pedoman Pemberian Produksi Pangan Industri Rumah Tangga. 